\title{
Insurgency in Jammu and Kashmir: Challenges and Response
}

\author{
Dr. Avneesh Kumar Verma, Assistant Professor, Department of Defence and Strategic Studies, Pt. Jawahar \\ Lal Nehru P.G. College, Banda, U.P. India. \\ Email: verma.avneesh2007@gmail.com \\ DOI: 10.29322/IJSRP.11.10.2021.p11836 \\ http://dx.doi.org/10.29322/IJSRP.11.10.2021.p11836
}

\begin{abstract}
India is a vast and diverse county. Peoples from different religion, ethnicities, language and culture are living together in India. They share their day to day life with each other. But some section of the society use this diversity as the reason of their plight. They indulge in the act of militancy. The Union Territory of Kashmir is facing the same situation. This paper is an attempt to find the reason behind the militancy in Jammu and Kashmir. This paper will try to understand the state response. Also this paper will try to suggest some measures to mitigate militancy from Jammu and Kashmir.
\end{abstract}

Key Words: Insurgency, Counterinsurgency, Conflict, Article 370, Militancy

\section{Introduction}

India is facing numerous irregular warfare within its border. On the northern part of India our security forces are facing the problem of separatist movement in Kashmir. On the north eastern border the same threat is posed by ethnic and linguistic separatist movement. Heartland of India is affected by left wing extremism. In such a way we can say that India is surrounded by multifaceted challenges of security threat. Broadly we can put all these security threat under one basket which is known as Insurgency. Among all these security threats Kashmir issue has much importance. But before going to understand the problem of Kashmir it would be wise for us to understand the meaning of insurgency so that we could acquaint with our topic

Numerous efforts have been made so for to define insurgency eighteenth century but these efforts get into reality after 1945. All existing studies depict insurgency as a warfare, however, look primarily at the political and social consequences and do not accurately explain insurgency as a separate facet in war making or as a separate strategic thought. Under these terms, any definition of insurgency as a war must appear incomplete. Typically the term insurgency is intertwined and often confused with other terms. A list of more prominent transpositions would include the following subversion, coup d'état' terrorism, guerrilla war, a revolution and even civil war ${ }^{1}$

To understand the real meaning of insurgency we need to consult the work of some famous expert on insurgency. One of the experts is David Galula. In his book "Counterinsurgency warfare : Theory and Practice" he explains that insurgency is a separate concept, a part of political revolution, plot and war. Galula lists three stages to this hierarchy: revolution, plot and insurgency. Galula points out an insurgency is a protracted struggle conducted methodically, step by step in order to attain specific intermediate objective leading finally to the overthrow of the existing order ${ }^{2}$. But his definition of insurgency is so vague that it is not able to differentiate between a civil war and insurgency, how insurgency is different from a protracted revolutionary war. In other words we can say that Galula makes no real distinction between insurgency war and other concepts, apparently using it in place of the phrase revolutionary war.

Another efforts to define insurgency has been made by Thomas R. Mockaitis. He differentiates between the terms insurgency and guerrilla warfare. The term 'guerrilla ' is Spanish for 'small war' and dates back to the Duke of wellington's Peninsular campaign during the Napoleonic era. Mockaits defines insurgency and insurgents in the following manner 'unlike the guerrilla, the insurgents seeks to gain control of a country from within and to reshape it in the image of some ideology. Insurgency, then, is a hybrid form of conflict that combines subversion, guerrilla warfare and terrorism ${ }^{3}$

After examining this explanation about insurgencies we can define insurgency as a strategic political development that implements these tactics as a means to sustain itself until further development can occur. Insurgency as a method of war, implies the attempt to use violence and irregular forms of warfare against a particular factions for the express purpose of political military gain, which may later lead to inclusion with or the overthrow of ,existing regimes.

This publication is licensed under Creative Commons Attribution CC BY. 
Therefore, an insurgency is neither revolution nor civil war. As well there are three major elements identified as tools used in an insurgency: political, subversion, selective terrorism and guerrilla operations. After explaining the definition of insurgency now it has become easy for us to understand how and on what way it is posing threat to India's internal security challenges.

\section{Research Methodology}

This research is based on historical analytical method as well as qualitative and quantitative research methodology. Content analysis method is used to analyse secondary sources. Co relational quantitative method is used to analyse primary sources.

\section{Historical Background}

After understanding the meaning of insurgency it has become easy for us to define the current situation of Jammu and Kashmir. Before independence India was under British supremacy. The population of India was mainly divided in two religions. One dominant group was the Hindu and the other was the Muslim. During British rule their differences was in dormant from which starts to become ugly as the date of independence was approaching near. In such chaotic environment India get its independence but after losing one of its part as a Pakistan.

India was partitioned in the backdrop of large scale communal riots but the partition of the country on religious lines, without taking into consideration its multiple identities, instead of bringing the communal tension down, in fact, worsened the situation of all these incidents have further complicated the internal security situation. Due to partition law and order situation get worsened which results in the form of communal tension between Hindu and Muslim.

In a well established political system and a developed economy, conflicts between the various group identities are kept under checks as in due course they get assimilated into the national identity. But that has not happened in India as yet, where the wounds of the partition and the colonial rule have still not fully healed .Moreover, the dependence on the government by a large section of our people for their very survival sharpens these conflicts among them. ${ }^{4}$ When some section of society could not succeed in mobilising the mainstream people for their cause they become rebel and want to annihilate the state. India is facing many such issues.

One of such issue is ongoing insurgency in Jammu and Kashmir. The conflict in Jammu and Kashmir had been started right after the independence of India and Pakistan. In order to capture the territory of Jammu and Kashmir, Pakistan sent their regular army personnel disguised as tribesman, who started a revolt among Muslim population. Initially, this uprising was successful and captured the territory that is presently considered Pakistan occupied Kashmir (POK). This incident forced Maharaja of Jammu and Kashmir to reach out for military assistance from the new Indian government in New Delhi. Responding to this request the Indian government put a condition before the Maharaja. Maharaja was instructed that without official request for accession into the new country of India, Indian Government is unable to send their troops in Jammu and Kashmir. ${ }^{5}$

On October 26, 1947 Indian government send their troops in Srinagar as soon as the Maharaja signed the instrument of accession. Indian troops repulsed the rebel army and reversed the Pakistani gains. Instruments of accession accepts full jurisdiction of India over the state of Jammu and Kashmir except the defence, foreign affairs and communication.

On the other hand at the same time when India was enjoying the gains of territory in Jammu and Kashmir ,the then Prime Minister Pt. Jawaharlal Nehru took this case to the United Nations to get a mandate for immediate Pakistani withdrawal ${ }^{6}$. The United Nations passed two resolutions that ordered a ceasefire, withdrawal of the Pakistani forces from Kashmir, a minimization of Indian forces in Jammu and Kashmir and a plebiscite.

First Pakistan refused to withdrawal its troops from its occupied part and later on, India refused to conduct plebiscite, fearing that the Muslim majority would vote to join Pakistan. As a consequence, neither side withdrawal its forces from the region, thereby spitting Kashmir in two parts. The armed conflict ended in 1949 when the U.N. mediated a ceasefire that drew a 500 mile border, splitting Jammu and Kashmir into the regions of the Indian and Pakistani occupied Kashmir depicted on today's maps, thus setting the stage for the longest dispute in the history of united nations. ${ }^{6}$

The secessionist movement gained a fillip after the 1987 state assembly elections amid widespread allegations of electoral malpractices. This largely unfair election was the catalyst causing secessionist to turn to lower level violence to voice their 
discontent. In addition to local Kashmiri insurgents fighting against the Indian government, foreign fighters began to arrive on the scene from Afghanistan, Pakistan and other Muslim countries from around the middle east to assist the insurgents in their struggle against the Indian rule.

\section{Changing nature of Insurgency}

From 2000 onwards the entries of the militant organisation like lashker taioba (LeT) and Jaish Mohammad(JM) and Harket ulMujahedeen opened a new chapter in the insurgent movement in J\&k . A majority of militants left the Harkat ul Mujahedeen and followed Azhar into the newly formed group called jaish Mohammed.

The attacks of LeT on security forces especially the series of Fedayeen attacks on security forces in Jammu and Kashmir and the attacks on Indian parliament in 2001 completely give the indigenous insurgent movement initiated by the local Kashmir's a different shape from insurgency to terrorism. Due to insurgency and the counterinsurgency campaign started by the Indian government hundreds of innocent people were killed from 1991 including the militants and security forces.

The internal discontent within the valley especially among the youth provided a conducive atmosphere for the external forces to operate there. The mobilization of new social group through employment and education without a corresponding outlet for democratic expression led to new forms of religious consciousness in a variety of setting. Sheikh Abdullah could not stop the growth of religious and extremist forces and faced with a new generation which could not appreciate the fact of his reconciliation with the central government.

\section{State response to insurgency in Jammu and Kashmir}

India's response has been consistent and driven by a support to civil authority doctrine. This approach stems from its adopting at independence from the former colonial power Britain . Insurgency therefore remains operationally first and foremost, an issue of law and order and this is to be met by reinforcing the normal mechanisms of the state most especially its local security forces. Though the military was interjected into the counterinsurgent dynamic in early 1990s and is clearly the dominant force in terms of sheer power, police primacy the template within which all force dispositions take place ${ }^{8}$.

This has meant in particular the establishment of a legal framework for carrying out counterinsurgency. A variety of national and state ordinances have been implanted, allowed to lapse, then been resurrected. The most prominent have been the Terrorist and Disruptive Activities (Prevention)Act 1987 or TADA and later the Act of 2002(POTA) ${ }^{9}$,special courts ,special measures for protection, all are stipulated. The result is that while armed response by the state is carried out with emergency legislation it remains subject to control by and challenge through the legal system.

For administrative purpose, J\&K is divided into 14 districts. These are the basic framework for the police district structure, but a number of administrative districts have been further divided into several police districts to improve command and control.

The intent is to provide layer upon layer of security forces in response to internal upheaval. Always, though, the point of reference is existing society with emergency manpower, such a recruited mainly in SPO. The proliferation of Para military forces over the past decades has been directed at providing an emergency response capability that nevertheless remains within the civil authority structure and does not distort the day to day realities of law enforcememnt ${ }^{10}$. Though violence in J\&K continues but these measures help the govt to create such an atmosphere under which moderate groups among the militants are ready for negotiation with India and state government. Such progress would not have been possible had the security forces not held the line.

Recently the Government of India abrogated article 370 of the constitution on August 5, 2019, thereby effectively ending the special status of Jammu and Kashmir. With this bold move India has targeted many marks with one arrow. This decision will help our security forces to neutralise militancy in the union territory. Now New Delhi hold on Kashmir will be stronger and Indian government can take decision more swiftly. However some reports are suggesting that after abrogation of article 370 incidents of terrorism has increased drastically. Terrorist outfits are recruiting their cadre mainly from local youth. ${ }^{11}$

But if we observe the incidents of militancy then it become clear that these attacks are carried out only to manifest their frustration. For example the table no 1 suggest us that after abrogation of article 370 incidents of killings increased from 135 in 2019 to 140 in 2020 but due to our vigilant security forces these incidents again decline to 91 . In the same way attack on army personnel suddenly rise from 3 in 2019 to 26 in 2020 but again it come down to 16 in 2021 . Thus we can say that the recent move 
taken by Indian government is a first step taken in a right direction which will mitigate militancy from Kashmir ghati very soon provided non coercive measures go hand in hand along with coercive measures.

\section{Table: 1}

\begin{tabular}{|l|l|l|}
\hline Year & Incident of Killings & Attack on Army Personnel \\
\hline 2016 & 112 & - \\
\hline 2017 & 163 & - \\
\hline 2018 & 206 & 4 \\
\hline 2019 & 135 & 3 \\
\hline 2020 & 140 & 26 \\
\hline 2021 & 91 & 16 \\
\hline Total & 847 & 39 \\
\hline
\end{tabular}

Source: South Asia Terrorism Portal, https://www.satp.org/security-force-data-details/Attacks-on-Army-Personnel/india-jammukashmir

\section{Conclusion:}

As this paper has argued that the situation in Union Territory of Jammu and Kashmir is improving day by day. Despite several efforts of Indian government sometimes terrorist get success in carrying out attack on civilians and security forces. After abrogation of article 370 the situation is tend to normalcy. But these efforts would become futile if the common citizen will not actively take part in the peace process. Common people only come forward when they are guaranteed that they will be protected by the government against the militants. Apart from this government should assured the people that no injustice will be done by the government against the innocent and common people. To boost the confidence among the common citizen it is necessary to develop and reform infrastructure and basic amenities in the region. Once we get the support of the people militancy automatically will be decline and will eventually get wane.

\section{References:}

1. Elyas, Md., 'Insurgency and Terrorism in India and Pakistan : with special reference to Benazir Butto,' MD Publications Pvt. LTD, New Delhi,2008.

2. Galula,David," Counterinsurgency warfare : Theory and Practice, PSI,London, 1964

3. R.Kaushik and Saurish Saha," Armed Forces And Insurgents in Modern Asia", Routledge, New York,2016.

4. https//idsa.in/strategicanalysis/Indias internal security challenges_vmarwah_1003

5. shodhganga.inflibnet.ac.in/bitstream/10603/156807/9/09_chapter\%202.pdf.

6. http://www.researchgate.net/profile/thomas_marks3/publication/263758276_India-State-Response-to-insurgency-in-jammu-kashmirthe-jammu-case/links/58f77f87a6fdcc66

7. N.Bashrat' Changing Nature of Insurgency in Kashmir:its impact on the Kashmirri cause of self determination with special reference to 2008 \&2010Agitations, European Academic Research -vol2.issue/Feb2015

8. Stephen Deakin," Security policy and the use of the military-military Aid to the Civil Power, Northern Ireland.1969,' small wars and Insurgencies ,vol no2,Autumn 1993

Arnab Goswami, Combating Terrorism:The Legal Challenge, Delhi: Har-Anand,2002.

Rekha Chaturvedi, Manual of Para Military Forces in India, Delhi Universal law Publishing,2001.

Peerzada Ashique, "Two years on as Union Territory, Kashmir militancy yet to wane" The Hindu, August 04, 2021.

https://www.satp.org/security-force-data-details/Attacks-on-Army-Personnel/india-jammukashmir. 